\title{
Copepod fecal pellets: abundance, sedimentation and content at a permanent station in the Norwegian Sea in May/June 1986*
}

\author{
U. V. Bathmann ${ }^{1}$, T. T. Noji ${ }^{1}$, M. Voss $^{1} \&$ R. Peinert ${ }^{2}$ \\ 1 Sonderforschungsbereich 313, Christian-Albrechts-Universität Kiel, Olshausenstr. 40, D-2300 Kiel, \\ Federal Republic of Germany \\ ${ }^{2}$ Institut für Meereskunde, Düsternbrooker Weg 20, D-2300 Kiel, Federal Republic of Germany
}

\begin{abstract}
Vertical distribution of fecal pellets and their sedimentation were studied during May and June 1986 at a permanent station on the Voering Plateau in the Norwegian Sea. Pellets were collected with water bottles as well as with moored time-series sediment traps and free-floating traps. Fecal pellets were counted, their carbon content was calculated and their composition was analyzed by scanning electron microscopy. Over $90 \%$ of all suspended and sedimented fecal pellets originated from copepods. Daily loss of suspended pellets from the upper $250 \mathrm{~m}$ of the water column via sedimentation was approx. $1 \%$ of fecal pellet standing stock. Between 10 and $90 \%$ of total sedimented material was attributable to these pellets; foraminifers and tintinnids accounted for the rest. It is suggested that most of the copepod pellets were broken down in the water column and/or were reingested (coprophagy). The chief constituent of both suspended and sedimented pellets was amorphous, hyalin material, in which small diatoms, coccolithophores and coccoliths were occasionally found; large diatoms or fragments were rare. Microflagellates, which were the main autotrophs, could not be recognized in the pellets. Thus, sedimented material does not necessarily reflect species composition and abundance of phytoplankton of the upper water layers.
\end{abstract}

\section{INTRODUCTION}

Zooplankton fecal pellets, including those of copepods, are thought to be important vehicles for transport of organic material to the deep sea and the sea floor (e.g. Wiebe et al. 1976, Honjo 1978, 1979, Turner \& Ferrante 1979, Silver \& Bruland 1981, Angel 1984). In many cases, however, sinking of copepod pellets out of the layer of their production is insignificant and contributes little to material reaching the sea floor (Smetacek 1980, 1984, Krause 1981, Honjo et al. 1982, Peinert 1985, Bathmann 1986). Findings from the above cited investigations were either based on flux rates of fecal pellets using sediment traps or distribution of fecal pellets in the water column; to our knowledge concomitant measurements of both were not made.

Other studies on copepod fecal pellets mainly

\footnotetext{
- Publication No. 16 of the SFB 313 at Kiel University
}

focused on content as a means of understanding copepod feeding ecology (e.g. Turner 1986, and the literature cited therein). These authors assumed that fecal pellet content reflects composition and abundance of food items. However, processes of selective feeding and differences in digestibility of food may lead to biased results. For example, if fragile naked flagellates are consumed, they probably would not show up as identifiable components of fecal pellets; hence, hard-shelled organisms may be overrepresented.

Two cruises into the Norwegian Sea during the time of phytoplankton spring growth (further details of phytoplankton and zooplankton dynamics are given by Peinert et al. unpubl.) provided the opportunity for simultaneous measurement of both in situ fecal pellet concentrations and their sedimentation rates at different water depths. An analysis of these findings as well as a discussion of the selective enrichment of identifiable material in copepod fecal pellets are presented. 


\section{MATERIAL AND METHODS}

A permanent station on the Voering Plateau in the Norwegian Sea was visited between 14 May and 30 June 1986 (Fig. 1). Enlarged versions of the Kiel-

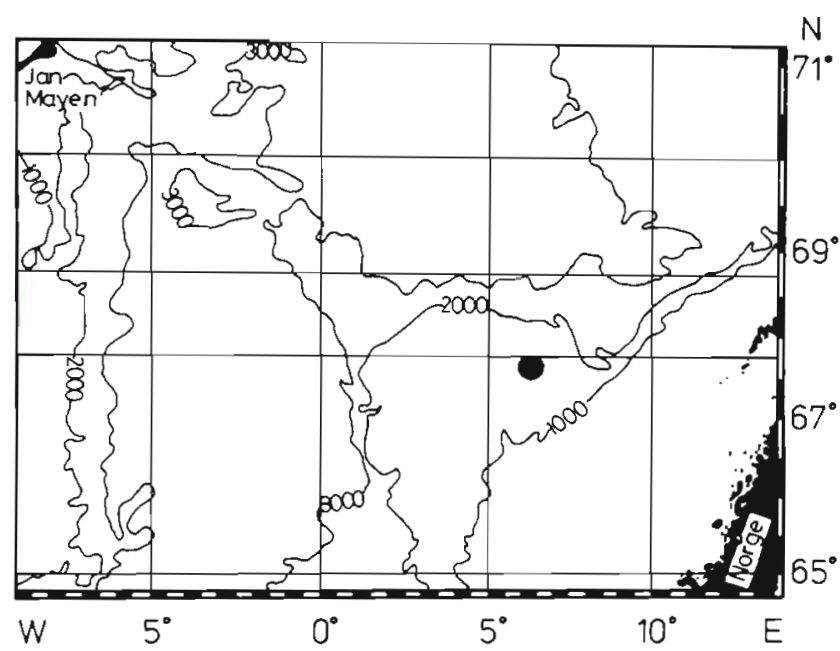

Fig. 1. Permanent station ( ) on the Voering Plateau (Norwegian Sea)

funnel ' multisample sediment traps (Zeitzschel et al. 1978), fitted with a grid to reduce inner turbulence and with an opening diameter of $0.7 \mathrm{~m}$, were moored at this station at 250 and $1000 \mathrm{~m}$ in May and 140, 350 and $950 \mathrm{~m}$ in June. Collecting intervals were between 24 and $60 \mathrm{~h}$. In addition, free-floating traps $(100 \mathrm{~m})$ were deployed for 18 to $30 \mathrm{~h}$ at a distance of not more than $10 \mathrm{n}$ miles from the mooring.

The sedimented material was preserved in situ in the collecting jars $(100 \mathrm{ml})$ with $0.5 \mathrm{ml}$ of chloroform. Collected material was split directly after recovery of the traps according to Noji et al. (1986). Aliquots of the samples were stored in a $1 \%$ formalin-seawater solution. From these, fecal material was identified and counted using an inverted microscope according to Utermöhl (1931, 1958). Fecal pellet carbon content (FPC) was calculated by measuring pellet volume and multiplying it by the factor 0.11 as specified for phytoplankton plasma (Strathmann 1967); this overestimates pellet carbon content (Smetacek 1980). For scanning electron microscopy with a Cambridge 180 SEM, pellets were transferred to $\mathrm{GF} / \mathrm{C}$ glass fiber filters, carefully rinsed with distilled water and gradually dehydrated using a water-alcohol dilution series according to Bathmann \& Liebezeit (1986). Total particulate organic carbon (POC) and nitrogen (PON) of non-formalin-fixed sedimented material were measured with a Hewlett-Packard CHN Analyzer (HP 185 B) using precombusted GF/C glass fiber filters.

Suspended fecal pellets at selected depths (indicated in Fig. 2) near the moored traps were concentrated from 10 to 90 l water collected with Niskin bottles using a $20 \mu \mathrm{m}$ sieve (Bathmann 1986). Pellets were analyzed in the same way as described for the sedimented material.

\section{RESULTS}

\section{Fecal pellet concentration in the water column}

Vertical distribution of fecal pellets is shown for selected water columns in Fig. 2. Maximum concentrations were generally found above $100 \mathrm{~m}$ depth; an absolute maximum value of $15 \mathrm{mg} \mathrm{FPC} \mathrm{m}^{-3}$ was found on 29 May. Thereafter, concentrations declined to less than $1 \mathrm{mg}$ FPC $\mathrm{m}^{-3}$. In depths below $200 \mathrm{~m}$ FPC was $\leq 0.5 \mathrm{mg} \mathrm{m}^{-3}$ throughout the investigation.

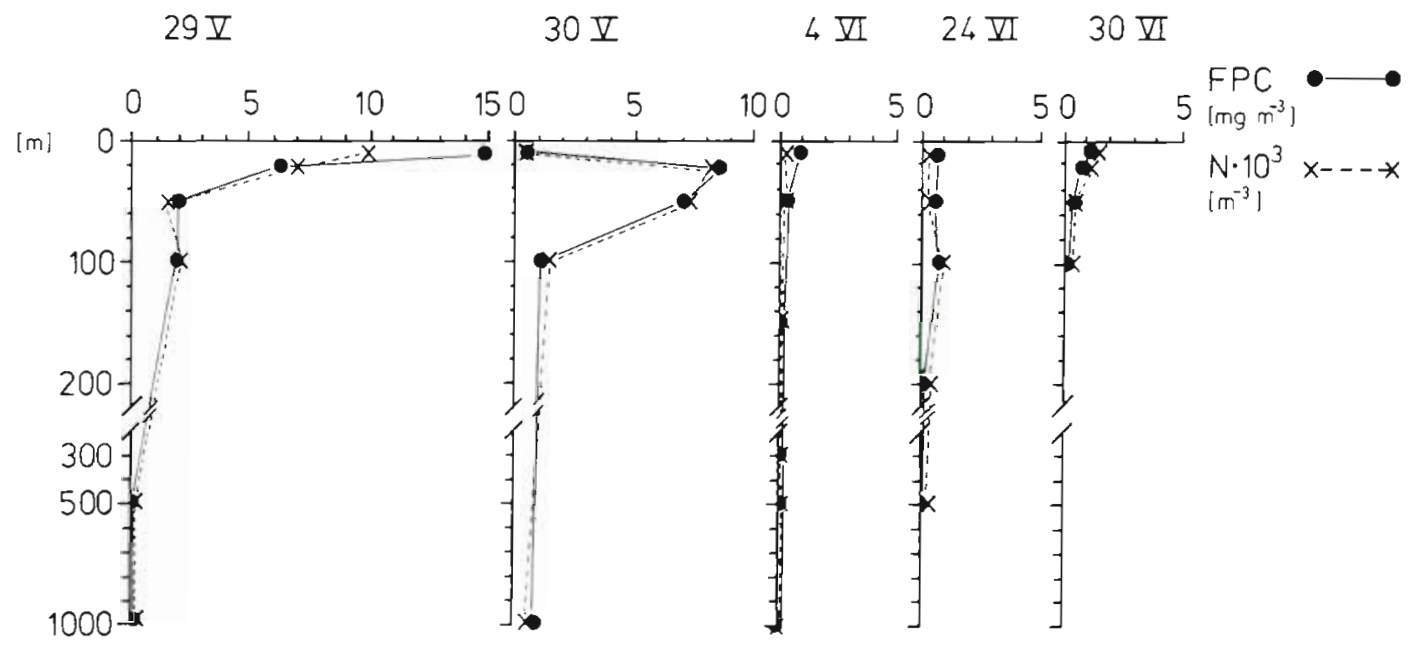

Fig. 2. Vertical distribution of fecal pellet numbers $(x)$ and fecal pellet carbon $(\bullet)$ in May and June at the permanent station on the Voering Plateau 
Table 1a. Suspended fecal pellet carbon (mg FPC m ${ }^{-2}$ )

\begin{tabular}{|lrrrrr|}
\hline $\begin{array}{c}\text { Depth } \\
(\mathrm{m})\end{array}$ & 29 May & 30 May & 4 Jun & 24 Jun & 30 Jun \\
\hline $0-100$ & 475 & 430 & 27 & 30 & 33 \\
$0-250$ & 620 & 580 & 73 & 67 & 60 \\
$0-1000$ & 995 & 1330 & 135 & 132 & 125 \\
\hline
\end{tabular}

Table 1b. Sedimented fecal pellet carbon (FPC) as \% of suspended FPC above sampling depth

\begin{tabular}{|cllcrr|}
\hline $\begin{array}{c}\text { Depth } \\
(\mathrm{m})\end{array}$ & 29 May & 30 May & 4 Jun & 24 Jun & 30 Jun \\
\hline $100 / 140$ & 1.3 & 2.1 & - & 5.6 & 11.5 \\
$250 / 350$ & 0.1 & 0.1 & 12.0 & 25.4 & 28.0 \\
1000 & 0.005 & 0.004 & 0.04 & 4.9 & 5.2 \\
\hline
\end{tabular}

The decrease in fecal pellet carbon in the upper $100 \mathrm{~m}$ water column from May to June is also evident in the integrated values over that depth interval. A stock of $475 \mathrm{mg} \mathrm{FPC} \mathrm{m}^{-2}$ at the end of May decreased to about $30 \mathrm{mg} \mathrm{FPC} \mathrm{m}^{-2}$ in June (Table 1a). This pattern was paralleled by a shift in the size of the fecal pellets. Whereas rather large pellets $(70 \times 900 \mu \mathrm{m})$ from Calanus finmarchicus adults dominated the spectrum in May, smaller pellets $(50 \times 600 \mu \mathrm{m})$, presumably from Calanus spp. copepodites, and pellets $(30 \times 300 \mu \mathrm{m})$ from other smaller copepods dominated in June and composed nearly $50 \%$ of total suspended feces.

\section{Fecal pellet sedimentation}

The average sedimentation of copepod fecal pellets in terms of numbers and carbon for May and June is shown in Fig. 3. The progressive reduction in sedimentation rates with depth is distinctly seen in May and is also evident in June. Total flux in June was slightly greater at all depths. A large proportion of sedimented fecal pellet carbon as well as numbers (cross-hatched areas in Fig. 3$)$ is attributable to large $(700 \mu \mathrm{m}$ length, $250 \mu \mathrm{m}$ maximum width), ellipsoidal fecal pellets of unknown origin. As amphipods and ostracods became particularly abundant in late June and composed up to about $15 \%$ of total zooplankters in some depth horizons below $250 \mathrm{~m}$ - no other zooplankton groups exhibited this increase -, they may be the source of these ellipsoidal forms.

A closer look at total flux for daily and $2 \mathrm{~d}$ sampling intervals (Fig. 4) reveals that at the 100 and $140 \mathrm{~m}$ depths, sedimentation increased by a factor of 20 from May to June with an irregular pattern from 24 to 29

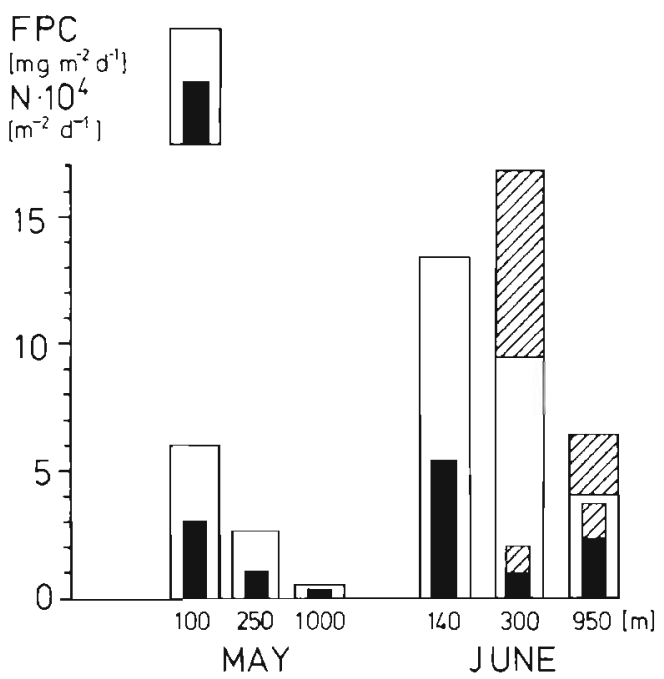

Fig. 3. Average sedimentation rates of numbers (N, small bars) and carbon in fecal pellets (FPC, large bars) for May and June on the Voering Plateau. White and black areas: copepod fecal pellets; cross-hatched areas: ellipsoidal pellets

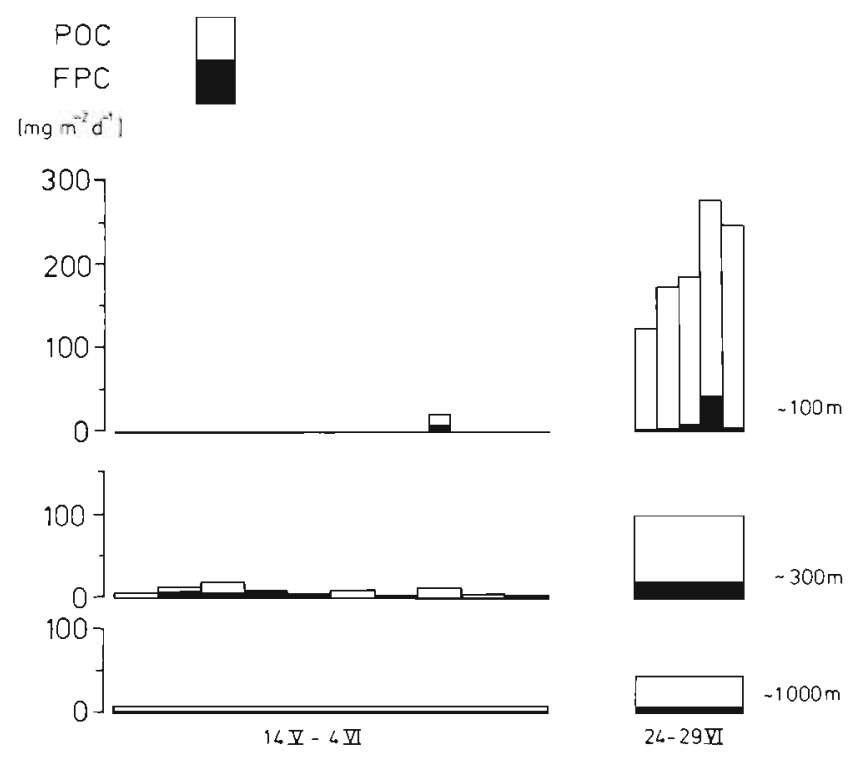

Fig. 4. Daily sedimentation rates of particulate organic carbon and fecal pellet carbon for 3 depth strata in May and June on the Voering Plateau

June. Sedimentation also increased, to a smaller degree, in the 300 and $1000 \mathrm{~m}$ depth. In May, when total flux at $100 \mathrm{~m}$ was below $20 \mathrm{mg}$ POC $\mathrm{m}^{-2} \mathrm{~d}^{-1}$. copepod FPC contributed up to $92 \%$ of total carbon sedimentation. In June the percentage of sedimented FPC from POC-flux was less than $10 \%$. Filled and empty shells of foraminifers, empty loricae of tintinnids and detritus composed the remainder of the sedimented material at that time (Peinert et al. unpubl.). 

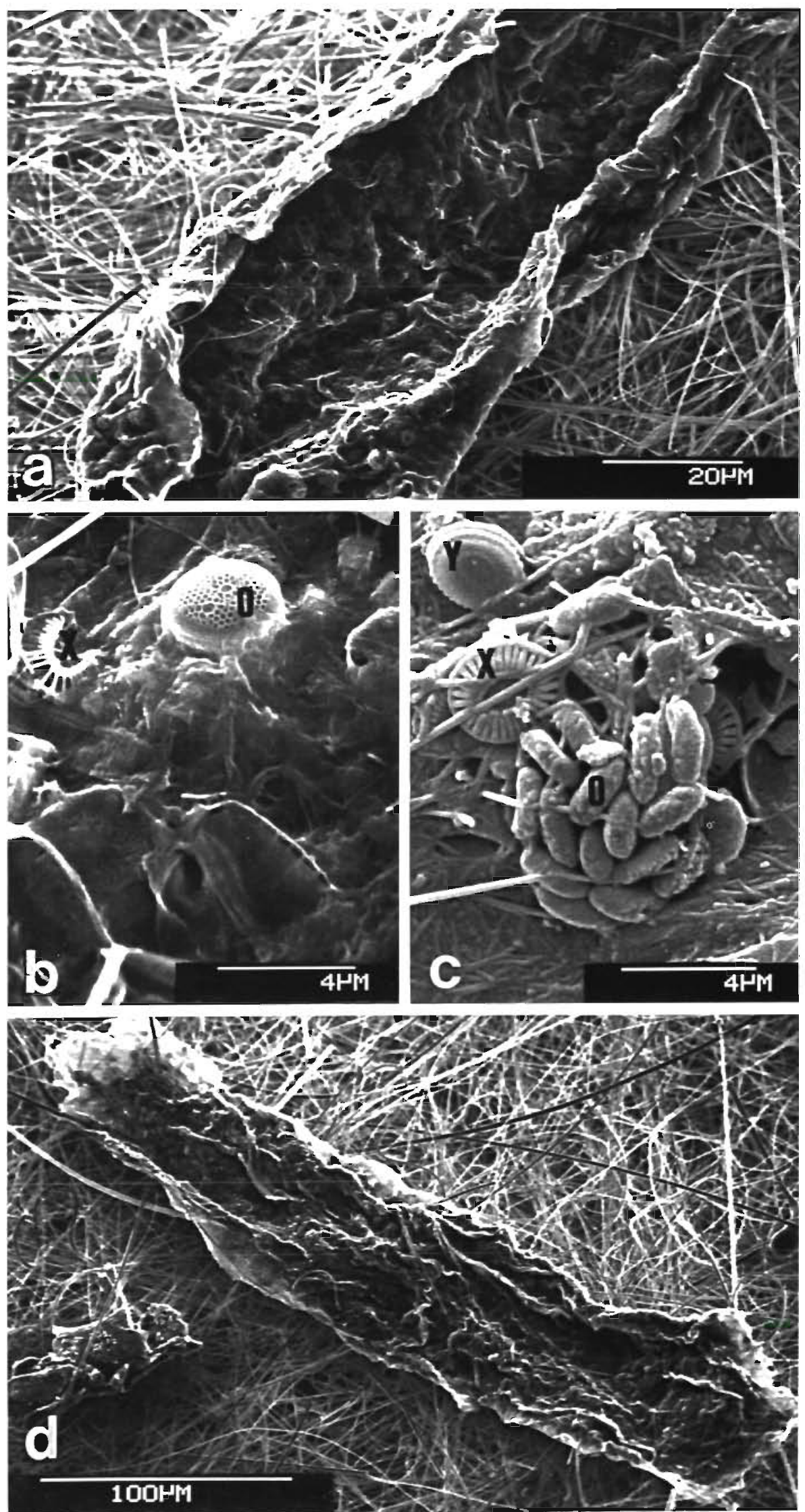

Fig. 5. Scanning electron micrographs from fecal pellets. (a) Copepod fecal pellet whose content shrank during drying process. Note the maintained cylindrical shape. (b) Content of the copepod fecal pellets mainly consists of amorphous detritus. Small centric diatoms (0) and coccoliths (X) were the only identifiable phytoplankton remains. (c) Two kinds of coccoliths were found in the sedimented fecal pellets: Anthosphaera oryza (0); Emiliania huxleyi, proximal view (Y): E. huxleyi, distal view (X). (d) Copepod fecal pellet on a glass fiber filter Note the flat shape which originated from drying procedure 
Comparison of the sedimentation rates of pellets relative to their standing stock is given in Table $1 \mathrm{~b}$. On 30 May, when fecal pellet standing stock was at its maximum, less than $0.1 \%$ of pellet carbon was exported daily out of the upper $350 \mathrm{~m}$. Thereafter, the percentage of sedimented to suspended FPC increased to $\geq 28 \%$ on 30 June.

\section{Content of fecal pellets}

The particulate content of the fecal pellets collected from the water column consisted mostly of fluffy, amorphous material which shrank and collapsed (Fig. $5 a)$ in the drying process during preparation for scanning electron microscopy. Small $(\leq 10 \mu \mathrm{m})$ diatoms and coccoliths of Emiliania huxleyi, Anthosphaera oryza (2 to $4 \mu \mathrm{m}$ ) were present in small numbers (Fig. 5c); intact cells or fragments of large diatoms were rare and the main pelagic autotrophs, namely microflagellates, were not recognizable in the fecal pellets.

Fecal pellets recovered in the sediment traps at 140 and $350 \mathrm{~m}$ had contents very similar to those of suspended pellets. SEM photomicrography again showed that pellet contents shrank and collapsed into long, flat sheets during drying (Fig. 5b). The identifiable portion of the contents consisted mainly of coccoliths (Fig. 5d); some diatom fragments were also observed. The ellipsoidal pellets contained particulate matter of the same ultrastructure as the copepod pellets.

When more than $50 \%$ of total sedimented POC was attributable to fecal pellets, C:N ratios of sedimented matter were about $7: 1$ (Table 2). When the fraction of fecal pellets was less than $50 \%$ and less than $20 \%$, C:N ratios were $10: 1$ and $13: 1$, respectively.

Table 2. C: $\mathrm{N}$ ratios of sedimented material

\begin{tabular}{|crc|}
\hline $\begin{array}{c}\text { Fecal pellet carbon as \% } \\
\text { of sedimented carbon }\end{array}$ & $\begin{array}{c}\text { Mean C:N } \\
\text { in atoms }\end{array}$ & $\mathrm{n}$ \\
\hline$>50 \%$ & $7.26 \pm 0.84$ & 5 \\
$20-50 \%$ & $9.86 \pm 1.54$ & 5 \\
$<20 \%$ & $12.55 \pm 4.65$ & 4 \\
\hline
\end{tabular}

\section{DISCUSSION}

In the period from May to June 1986 total carbon sedimentation out of the surface layers on the Voering Plateau did not exceed $1 \%$ of suspended POC (Peinert et al. unpubl.). Sinking of copepod fecal pellets contributed less than $20 \%$ to this total carbon flux with the only exception during $8 \mathrm{~d}$ in May (95\%). Absolute maximum flux of copepod fecal pellets was $5 \mathrm{mg}$ FPC $\mathrm{m}^{-2} \mathrm{~d}^{-1}$, which is equivalent to the carbon content (POC) of only $0.1 \mathrm{~m}^{-3}$ water in the euphotic zone. Thus, sedimentation of pellets was negligible for the overall loss of carbon from the euphotic zone during this investigation.

The figures, however, should be qualified, since the conversion from fecal pellet volume to carbon content was made as for intact phytoplankton cells. Such a conversion overestimates pellet carbon content. Hence, our FPC sedimentation rates should be viewed as maximum values, which emphasizes our conclusion that the loss of particulate organic carbon via pellet sinking was of little quantitative importance for the euphotic zone in the Norwegian Sea in early summer 1986

As the loss of copepod fecal pellets from the euphotic zone was less than $5 \%$ of their standing stock (29 and 30 May, Table 1b) it is assumed here that the bulk of those pellets remained in the layer of their production. The compact oval pellets, however, which occurred in the trap material at the end of June, accounted for the relatively high loss rates of suspended pellets. A review of fecal pellet sinking from various geographical locations was given by Angel (1984). Sinking of feces is believed by some authors to be the main process of vertical transport for pelagically produced material to deep ocean ecosystems (e.g. Fowler \& Small 1972, Honjo \& Roman 1978, Iseki 1981, Honjo 1982). However whereas the importance of feces as a mode of vertical flux is evident for some fecal forms such as euphausiid fecal strings (Bodungen 1986), in our opinion a general statement concerning their role in vertical transport is not justified. For example, some authors have indicated that fecal pellets from copepods do not always sink out of the surface zone (Smetacek 1980, 1984, Krause 1981, Peinert 1985, Bathmann 1986, Bathmann \& Liebezeit 1986). It has been suggested that pellets do not sink rapidly if: (1) they are of large volume relative to specific weight (e.g. salp pseudofeces; Madin 1982), (2) they are very small (minipellets; Gowing \& Silver 1985), (3) they are eaten shortly after production (coprophagy; Frankenberg \& Smith 1967), (4) they are degraded rapidly by microbes (Honjo \& Roman 1978), or (5) if microbial gas production inside the peritrophic membrane induces positive buoyancy (Krause 1981).

In our investigation a combination of Factors 1, 3, 4 and 5 mentioned above might be responsible for the recorded low pellet sedimentation rates. The shrinking of the copepod fecal pellets during preparation for SEM indicates their sparsely packed content and, thus, their low specific weight. Consequently, the sinking velocity of copepod fecal pellets must have been low. This is supported by their low rates of sedimentation as compared with concentrations of suspended copepod 
pellets. Due to their assumed long residence time in the water column, the probability of breakage and/or reingestion and the possibility of degradation by bacteria are much larger than for compact, fast sinking feces.

The identifiable components of primary producers in the pellets originate exclusively from organisms with inorganic skeletons (coccoliths or diatom valves), which may pass the gut of herbivores without damage. Microflagellates and holotrich ciliates, both of which were abundant in the water column, could not be identified in feces although these plankters are common food for copepods in high latitudes (e.g. Barthel 1986)

Two major conclusions for the Norwegian Sea in early summer 1986 can be drawn from these observations. Firstly, the characterization of copepod feeding behavior as based on the content of feces is a limited undertaking and should be recognized as such. In our investigation copepod fecal material did not contain identifiable remains of all pelagic autotrophs present. Only certain, and very few, representatives (e.g. coccolithophores) were found in the pellets, whereas the main primary producers could not be identified although they were presumably ingested.

Secondly, because of their low sedimentation rates, copepod fecal pellets did not contribute appreciably to the loss of essential elements from the upper water layers in the Norwegian Sea in early summer 1986. This is evident from $\mathrm{C}: \mathrm{N}$ ratios of sedimented material, as the C:N ratios decrease with increasing pellet carbon in the sedimented matter. This indicates the higher nitrogen content of pellets compared with other sedimented material. As the majority of the copepod fecal pellets ramained in the water column at or near their depth of production, grazing by copepods apparently hindered a loss of essential elements such as nitrogen to deeper water layers.

The fate of the copepod pellets presented here is strongly linked with processes in the euphotic zone and has consequences for the food supply of the mid- and deep-water layers and for the benthos. Grazing by copepods can apparently strongly influence spring phytoplankton development (Halldal 1953) and, consequently, spring sedimentation in the Norwegian Current (Peinert et al unpubl.). As described here, sedimentation during our investigation was minimal. In addition, according to a nitrogen budget constructed parallel to this study by Peinert et al. (unpubl.), a phytoplankton spring bloom and, hence, large sedimentation of freshly produced material could not have occurred earlier that year. We at least partially attribute this to grazing by copepods and the reduced sinking of their fecal pellets. Moreover, pelagic food input to deep-water layers and to the sea-floor must consequently have been small; incoming food items were probably utilized several times by the members of the pelagic community and presumably were of low nutritional value relative to intact phytoplankton cells. In this respect, copepod grazing may necessitate a tremendous adaptability to long periods of minimal food supply in bathypelagic and benthic communities, which use sedimented matter as a food source.

Acknowledgements. This study was supported by the Deutsche Forschungsgemeinschaft as part of Joint Research Program (SFB) 313 at Kiel University. We thank captains, officers and crews of RV Meteor and RV Poseidon for their help at sea; chief scientists G. Graf and S. Gerlach provided splendid organisation. Help with the SEM was provided by $W$. Reimann; photographic work was done by U. Schuldt and $M$. Mempel. Thanks are due to B. v. Bodungen, J. Lenz, E.-M. Nöthig and $U$. Passow and to 3 anonymous reviewers for improving the manuscript.

\section{LITERATURE CITED}

Angel, M. V. (1984). Detrital organic fluxes through pelagic ecosystems. In: Fasham, M. J. R. (ed.) Flows of energy and materials in marine ecosystems. Nato Conference Series IV. Mar. Sci. 13: 475-516

Barthel, K.-G. (1986). Die Bedeutung dominanter Copepodenarten für das Nahrungsgefüge verschiedener typischer Wassermassen der Framstraße. Dissertation, Univ. Kiel

Bathmann, U. (1986). Zooplanktonpopulationen dreier nordatlantischer Schelfe: Auswirkungen abiotischer und biotischer Faktoren. Ber. SFB 313, Univ. Kiel 3: 1-93

Bathmann, U., Liebezeit, G. (1986). Chlorophyll in copepod faecal pellets: changes in pellet numbers and pigment content during a declining Baltic spring bloom. P.S.Z.N. Mar. Ecol. 7: 59-73

Bodungen, B. von (1986). Phytoplankton growth and krill grazing during spring in the Bransfield Strait, Antarcticaimplications from sediment trap collections. Polar Biol. 6 : 153-160

Fowler, S., Small, L. (1972). Sinking rates of euphausiid fecal pellets. Limnol. Oceanogr. 17: 293-296

Frankenberg, D., Smith, L. F., Jr. (1967). Coprophagy in marine animals. Limnol. Oceanogr. 12: 443-450

Gowing, M. M., Silver, M. W. (1985). Minipellets: a new and abundant size class of marine fecal pellets. J. mar. Res. 43: 395-418

Halldal, P. (1953). Phytoplankton investigations from Weather Ship $M$ in the Norwegian Sea, 1948-49. Havalrad. Skr. 38: $1-91$

Honjo, S. (1978). Sedimentation of materials in the Sargasso Sea at a 5,367 m deep station. J. mar. Res. 36: 469-492

Honjo, S. (1979). Material flux and models of sedimentation in the mesopelagic and bathypelagic zones. J. mar Res. 38 : $53-97$

Honjo, S. (1982). Seasonality and interaction of biogenic and lithogenic particulate flux at the Panama Basin. Science 218: 883-884

Honjo, S., Manganini, S. J., Cole, J. J. (1982). Sedimentation of biogenic matter in the deep ocean. Deep Sea Res. 29 : $609-626$

Honjo, S., Roman, M. (1978). Marine copeod fecal pellets: 
production, preservation and sedimentation. J. mar. Res. 36: $45-57$

Iseki, K. (1981). Particulate organic matter transport to the deep sea by salp fecal pellets. Mar. Ecol. Prog. Ser. 5: $55-60$

Krause, M. (1981). Vertical distribution of fecal pellets during FLEX '76. Helgoländer Meeresunters. 34: 313-327

Madin, L. P. (1982). Production, composition and sedimentation of salp fecal pellets in oceanic waters. Mar. Biol. 67: $39-45$

Noji, T., Passow, U., Smetacek, V. (1986). Interaction between pelagial and benthal during autumn in Kiel Bight. I. Development and sedimentation of phytoplankton blooms. Ophelia 26: 333-349

Peinert, R. (1985). Saisonale und regionale Aspekte der Produktion und Sedimentation von Partikeln im Meer. Ber. SFB 313, Univ. Kiel 2: 1-108

Silver, M., Bruland, K. (1981). Differential feeding and fecal pellet composition of salps and pteropods, and the possible origin of the deep-water flora and olive-green "cells". Mar. Biol. 62: 263-273

Smetacek, V. (1980). Zooplankton standing stock, copepod faecal pellets and particulate detritus in Kiel Bight. Estuar. coast. mar. Sci. 11: $477-490$
Smetacek, V (1984). The supply of food to the benthos. In: Fasham, M. (ed.) Flows of energy and materials in marine ecosystems. Nato Conference Series IV. Mar. Sci. 13: $517-548$

Strathmann, R. R. (1967). Estimating the organic carbon content of phytoplankton from cell volume or plasma volume. Limnol. Oceanogr. 12: 411-418

Turner, J. T. (1986). Zooplankton feeding ecology: content of fecal pellets of the copepod Undinula vulgaris from continental shelf and slope waters of the Gulf of Mexico. P.S.Z.N. Mar. Ecol. 7: 1-14

Turner, J. T., Ferrante, J. G. (1979). Zooplankton fecal pellets in aquatic ecosystems. Bioscience 29: 670-677

Utermöhl, H. (1931). Über das umgekehrte Mikroskop. Verh. Int. Verein. theor. angew. Limnol. 5: 567-596

Utermöhl, H. (1958). Zur Vervollkommnung der quantitativen Phytoplankton-Methodik. Mitt. int. Verein. theor. angew. Limnol. 9: 1-38

Wiebe, P., Boyd, S., Winget, C. (1976). Particulate matter sinking to the deep-sea floor at $2000 \mathrm{~m}$ in the Tongue of the Ocean, with description of a new sediment trap. J. mar. Res. 34: 341-354

Zeitzschel, B., Diekmann, P., Uhlmann, L. (1978). A new multisample sediment trap. Mar. Biol. 45: 285-288

This article was submitted to the editor; it was accepted for printing on March 26, 198 ? 